\title{
A NEW SPECIES OF BYTHINELLA MOQUIN-TANDON, 1855 (CAENOGASTROPODA: TRUNCATELLOIDEA) FROM NAXOS ISLAND, GREECE
}

\author{
ANDRZEJ FALNIOWSKI ${ }^{1 *}$, SEBASTIAN HOFMAN ${ }^{2}$, ALEKSANDRA RYSIEWSKA ${ }^{1}$ \\ ${ }^{1}$ Department of Malacology, Institute of Zoology, Jagiellonian University, Gronostajowa 9, 30-387 Cracow, \\ Poland (e-mail: andrzej.falniowski@uj.edu.pl) \\ ${ }^{2}$ Department of Comparative Anatomy, Institute of Zoology, Jagiellonian University, Gronostajowa 9, \\ 30-387 Cracow, Poland \\ *corresponding author
}

ABSTRACT: A new species of Bythinella: B. walensae is described from Aria spring at Naxos Island, Greece. Cytochrome oxidase subunit I (COI) sequences of mtDNA, as well as internal transcribed spacer (ITS-1) of nuclear ribosomal DNA indicate distinctness of $B$. walensae. The shell, female reproductive organs and penis are described. The most characteristic of this species are: slender shell, narrow aperture, J-shaped bursa coupled with bulky and spherical receptaculum, and the length ratio of penis arms. Simple anatomy coupled with wide variation ranges overlapping between the species are emphasised.

KEY WORDS: molecular distinctness, mtDNA, cytochrome oxidase subunit I (COI), ITS-1, morphological distinctness, shell, penis, female reproductive organs

\section{INTRODUCTION}

The genus Bythinella Moquin-Tandon, 1855 is a group of freshwater, dioecious, oviparous snails inhabiting springs and subterranean waters (GIUSTI \& PeZZOLI 1977, FALNIOWSKI 1987). Its wide range extends from the Iberian Peninsula to western Asia, and from southern Poland to southern Greece. The diversity of Bythinella has mainly been studied in western, southern and central Europe (BOETERS 1973, 1998, GIUsTI \& PEZZOLI 1977, FALNIOWSKI 1987), but the studies have mostly focussed on the external morphology and anatomy, initially of just the shell and, later, of the soft parts. It has been demonstrated, however, that morphology alone cannot be used for unequivocal species delimitation due to the limited number of taxonomically useful characters and their wide variation (FALNIOWSKI 1987, 1992, SZAROWSKA 2006, BICHAIN et al. 2007a, b, FALNIOWSKI et al. 2009a). More recent studies using molecular data have made it possible to distinguish several Bythinella species and also to synonymise a few nominal species (BICHAIN et al. 2007a, b, HAASE et al. 2007, BenKE et al. 2009, FALNIOWSKI et al. 2009a, b, 2012b, FALNIOWSKI \& SZAROWSKA 2011, 2012).

Several species of Bythinella have been described across Europe, mainly in western and central parts of the continent (e.g. RADOMAN 1976, 1983, BICHAIN et al. 2007a, b). In contrast, relatively few Bythinella species have been identified in Greece and those that have been were initially identified based on morphological characters (RADOMAN 1976, 1983, SCHÜTT 1980, REISCHÜTZ et al. 2008). More recent research combining morphology and genetic markers, cytochrome oxidase subunit I (COI) and internal transcribed spacer (ITS-1), revealed eight putatively distinct species in continental Greece: two in the Peloponnese, one in the Attica and Parnassos Mts (Central Greece), one on Lefkas Island and four in northern Greece (FALNIOWSKI \& SZAROWSKA 2011, 2012). During our research on the Aegean Bythinella (SZAROWSKA et al. 2016) we found seven more molecularly distinct clades, of presumably species level. 
The most distinct was the one inhabiting two springs at Naxos Island. For COI the $p$-distances between the clade inhabiting Naxos and the other clades were within $0.065-0.090$, mean 0.080 for Naxos and the

\section{MATERIAL AND METHODS}

About ten specimens of Bythinella were collected at locality N01 (Fig. 1): small spring at Aghio Kyriaki, $37^{\circ} 04^{\prime} 09.6^{\prime \prime} \mathrm{N}, 25^{\circ} 26^{\prime} 48.9^{\prime \prime} \mathrm{E}$. About twenty specimens were collected at locality N02 (Fig. 1), in a somewhat bigger spring Aria (Aria Pygi), $37^{\circ} 02^{\prime} 11.1^{\prime \prime} \mathrm{N}$, $25^{\circ} 29^{\prime} 37.8^{\prime \prime}$ E. Snails were collected by hand or sieve, and fixed with $80 \%$ ethanol. The shells and soft parts were photographed with a CANON EOS 50D digital camera, under a NIKON SMZ18 microscope with dark field and phase contrast. Five males and five females were dissected, the drawings were made from the photographs. A NIKON DS-5 digital camera measurement system was used to measure seven shell morphometric parameters (SZAROWSKA 2006, FALNIOWSKI et al. 2012b). For definitions of character states see HERSHLER \& PONDER (1998), for the molecular data, and the results of Principal Component Analysis see SZAROWSKA et al. (2016).

Fig. 1. Map of Naxos Island showing two localities inhabited by Bythinella walensae $\mathrm{n}$. sp.

\section{SYSTEMATIC PART}

\section{Family: Bythinellidae Germain, 1930}

Genus: Bythinella Moquin-Tandon, 1855

\section{Bythinella walensae sp. $\mathrm{n}$.}

Types. Twelve ethanol-fixed specimens from spring

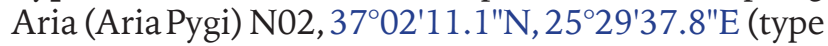
locality), September 2013, holotype: ZMUJ-M.1982, paratypes: ZMUJ-M.1983 - ZMUJ-M.1993; a few empty shells from a small spring at Aghio Kyriaki, N01; 3704'09.6"N, 25²6'48.9"E, September 2013. The other ten paratypes destroyed for DNA extraction. Ten sequences of cytochrome oxidase subunit I (COI), GenBank numbers: KT353699-KT353700 from locality N01 (Aghio Kyriaki); KT353701KT353708 from the type locality N02 (Aria Pygi). other Aegean clades, and 0.741 for Naxos and all the Greek Bythinella (SZAROWSKA et al. 2016). For ITS-1 the mean values were 0.036 and 0.043 , respectively (SZAROWSKA et al. 2016).

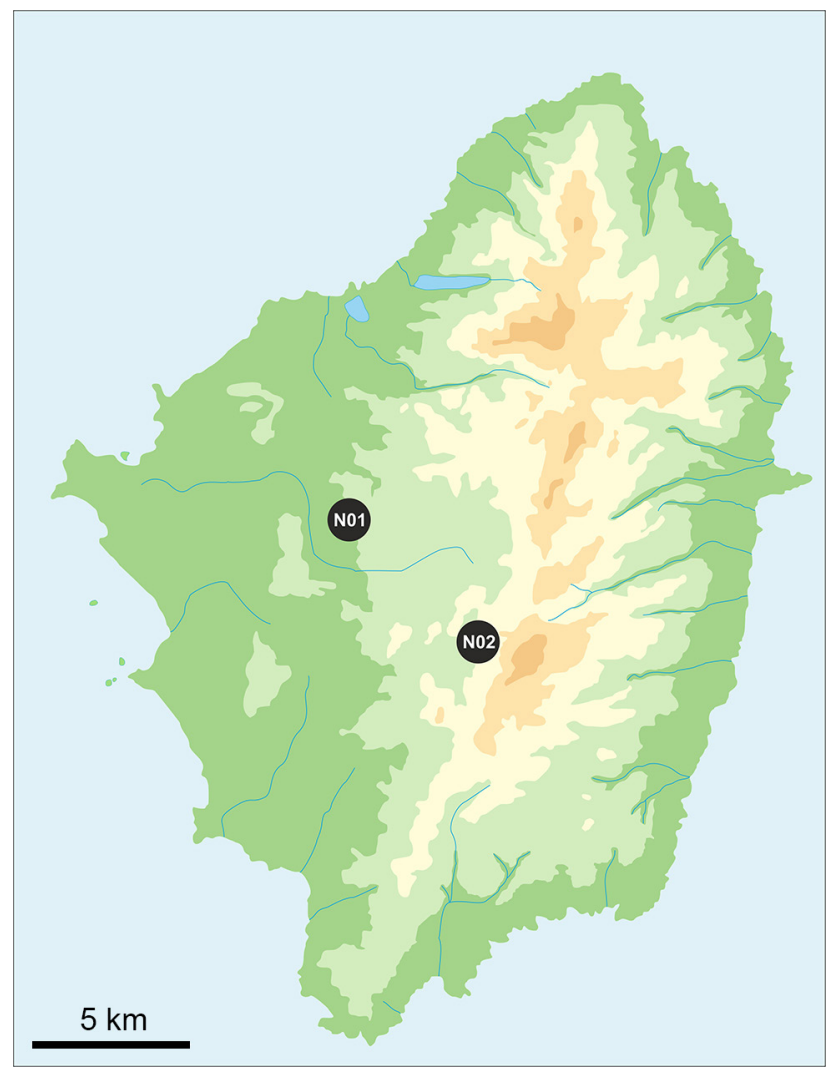

Ten sequences of internal transcribed spacer ITS-1, GenBank numbers: KT353614-KT353615 from locality N01 (Aghio Kyriaki), and KT353616-KT353623 from the type locality N02 (Aria Pygi) (SZAROWSKA et al. 2016).

Diagnosis. Shell ovate-conical, with relatively high spire and simple outer lip, soft parts pigmented black, female reproductive organs with big J-shaped bursa copulatrix, big spherical receptaculum seminis, and long and narrow loop of renal oviduct, penis with flagellum and the arm containing vas deferens of similar length, narrow, especially the arm containing vas deferens. The most characteristic of this species are: slender shell, narrow aperture, J-shaped bursa coupled with bulky and spherical receptaculum, and the length ratio of penis arms. 


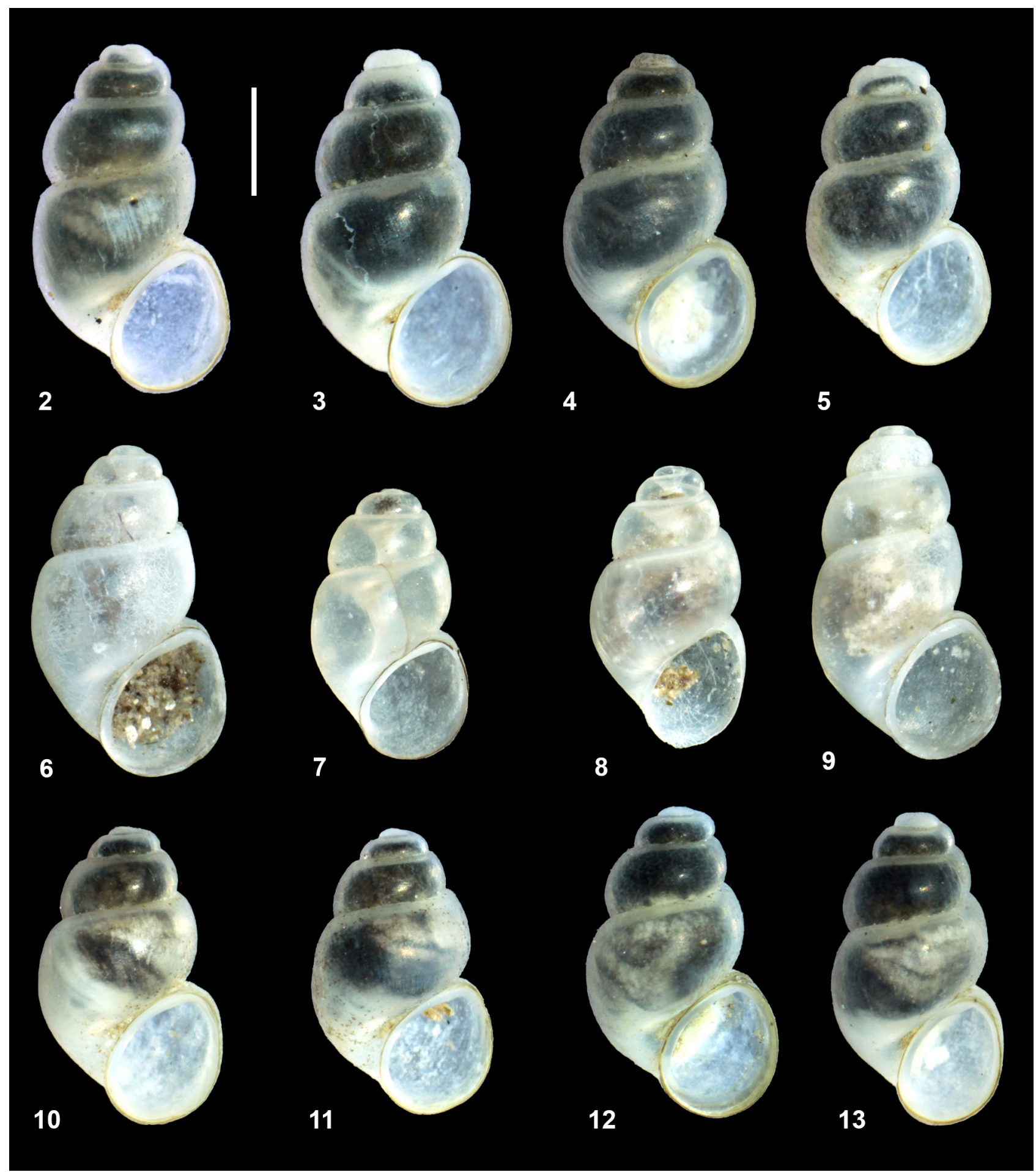

Figs 2-13. Shells of Bythinella walensae n. sp. from the type locality: 3 - holotype; bar equals $1 \mathrm{~mm}$

Description. Shell (Figs 2-13) ovate-conical with relatively high spire, up to $3.16 \mathrm{~mm}$ high, with ca 4.5 whorls, spire height approximately $30 \%$ of shell height, and $59 \%$ of body whorl width. Teleoconch whorls moderately convex, evenly rounded, growing regularly in diameter. Aperture ovoid, outer lip simple, parietal lip complete, umbilicus slit-like. Teleoconch glossy, with delicate growth lines, periostracum whitish or white. Shell parameters for a series of paratypes are given in Table 1. Operculum smooth on its inner and outer surface.

Soft parts densely pigmented black. Female reproductive organs (Figs 14-15) with big, broad, J-shaped bursa copulatrix with moderately long duct, one big, spherical receptaculum seminis in the position of $\mathrm{rs}_{1}$, and long and narrow loop of renal oviduct. Penis (Figs 16-21) with moderately long penial gland (Figs 17, 17a, 21), its arms of similar length, narrow, es- 
Table 1. Shell biometry of the holotype and paratypes $(n=10)$ of Bythinella walensae from Naxos Island: a - shell height, $\mathrm{b}$ - body whorl width, $\mathrm{c}$ - aperture height, $\mathrm{d}$ - spire height, e - aperture width, $\alpha$ - apex angle, $\beta$ - angle between body whorl suture and horizontal surface (see Fig. 23); $\mathrm{M}$ - mean, SD - standard deviation, max - maximum, min - minimum. The a $-\mathrm{e}$ in $\mathrm{mm}, \alpha-\beta$ in degree angle

\begin{tabular}{lccccccc}
\hline & $\mathrm{a}$ & $\mathrm{b}$ & $\mathrm{c}$ & $\mathrm{d}$ & $\mathrm{e}$ & $\alpha$ & $\beta$ \\
\hline Holotype & 3.16 & 1.64 & 1.30 & 1.02 & 1.15 & 117 & 17 \\
\hline $\mathrm{M}$ & & \multicolumn{7}{c}{ Paratypes $(\mathrm{n}=10)$} \\
$\mathrm{SD}$ & 2.94 & 1.49 & 1.26 & 0.88 & 1.10 & 129.1 & 18.12 \\
$\max$ & 0.21 & 0.11 & 0.08 & 0.13 & 0.05 & 11.41 & 1.73 \\
$\min$ & 3.16 & 1.64 & 1.37 & 1.05 & 1.17 & 145 & 21 \\
\hline
\end{tabular}

pecially the arm containing the terminal part of vas deferens.

Etymology. Named in honour of President Lech Wałęsa, a Polish national hero and co-creator of our independence.
Distribution and habitat. Known from the type locality (Aria spring), but also from another locality at Naxos Island (spring at Aghio Kyriaki).

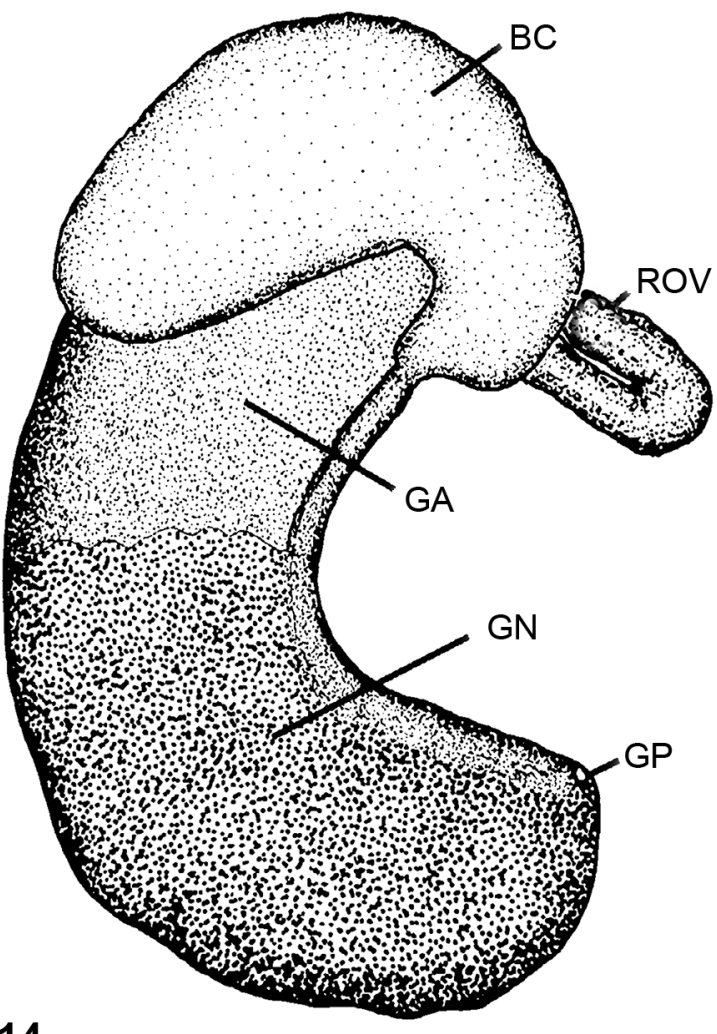

14

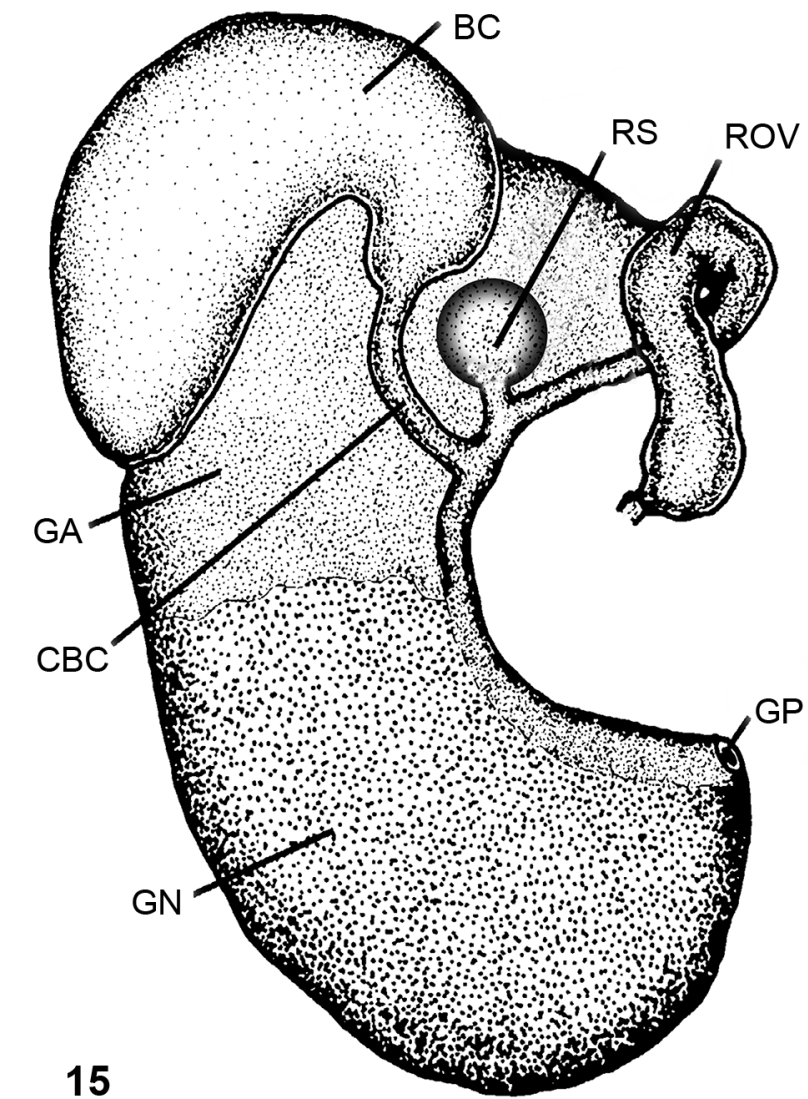

15

Figs 14-15. Renal and pallial section of female reproductive organs of Bythinella walensae n. sp.: 14 - bursa and coil of oviduct in natural position, 15 - bursa and coil bent, to show seminal receptacle (BC - bursa copulatrix, CBC - duct of bursa copulatrix, GA - albumen gland, GN - capsule gland, GP - gonoporus, ROV - coil of oviduct, renal oviduct, $\mathrm{RS}$ - seminal receptacle) 


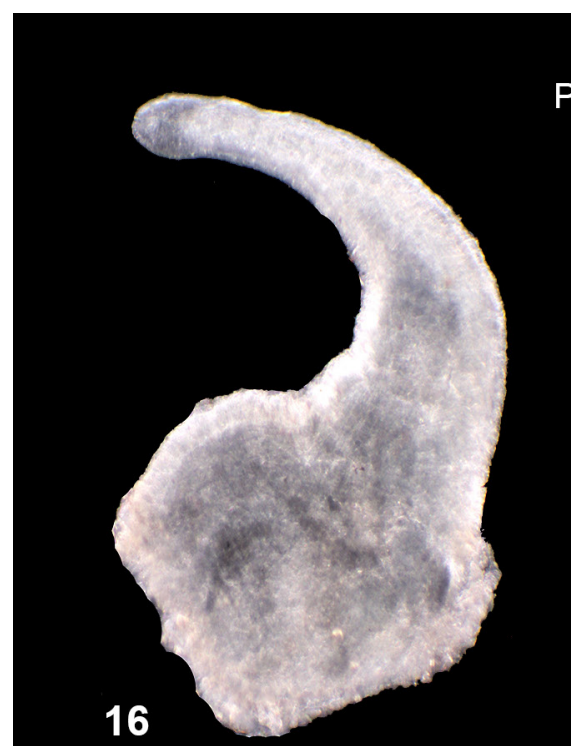

$\mathbf{P}$

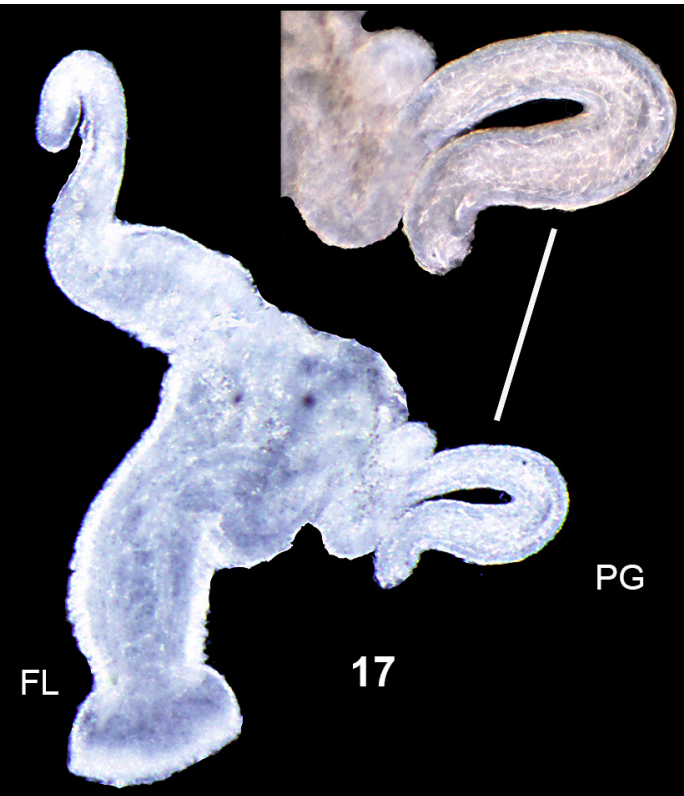

$17 a$

16

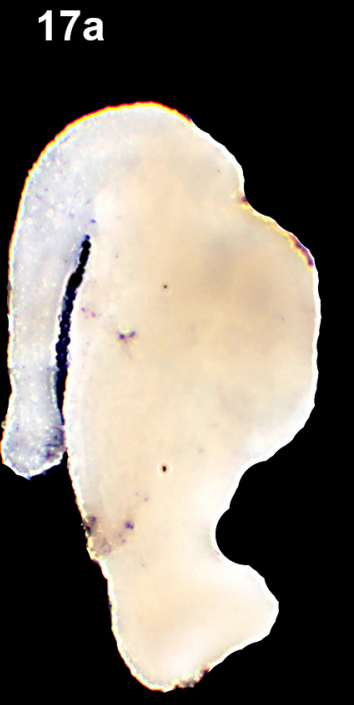

18

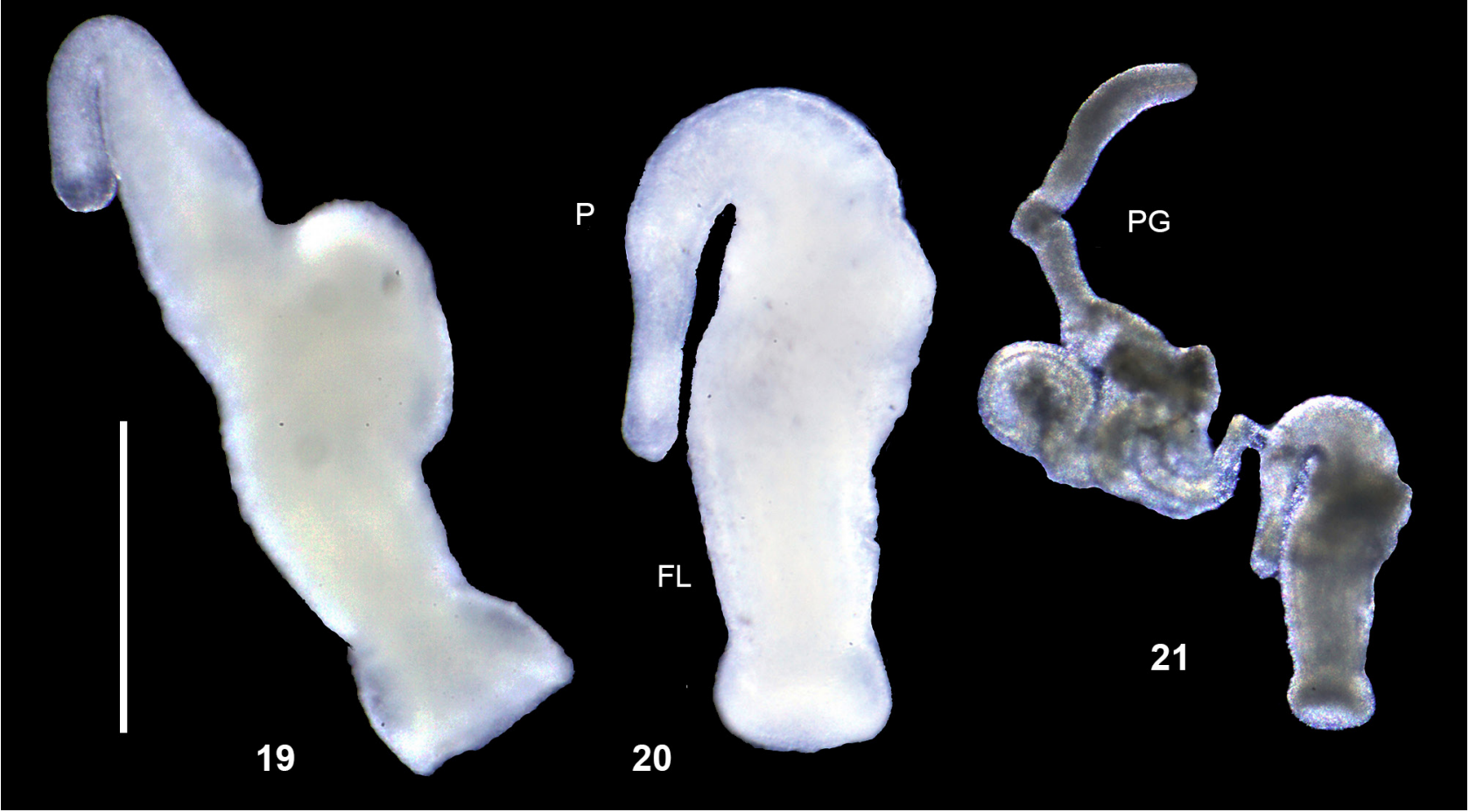

Figs 16-21. Penes of Bythinella walensae n. sp.: 17 and 21 - with penial gland, $17 \mathrm{a}$ - penial gland of specimen 17 (P - penis, FL - flagellum, PG - penial gland); scale bar equals $0.5 \mathrm{~mm}$

\section{DISCUSSION}

Species boundaries in Bythinella are still unclear, despite hundreds of sequences now available in the GenBank (FALNIOWSKI 1987, 1992, BICHAIN et al. 2007a, b, SZAROWSKA \& FALNIOWSKI 2008, BENKE et al. 2009, FALNIOWSKI \& SZAROWSKA 2011, 2012, SZAROWSKA et al. 2016). The simple and highly variable morphology is not sufficient even for species determination, thus molecular data are necessary. In Greece there are several molecularly discernible clades, most of them of species level. However, they have not been described so far, thus we cannot present formal differential diagnoses between $B$. walensae and its closest relatives. B. walensae is molecularly more distinct than the other still unnamed clades (Fig. 22).

The shell height, spire height and aperture height had the highest loadings in PC1, and the angle between the body whorl suture and the horizontal sur- 


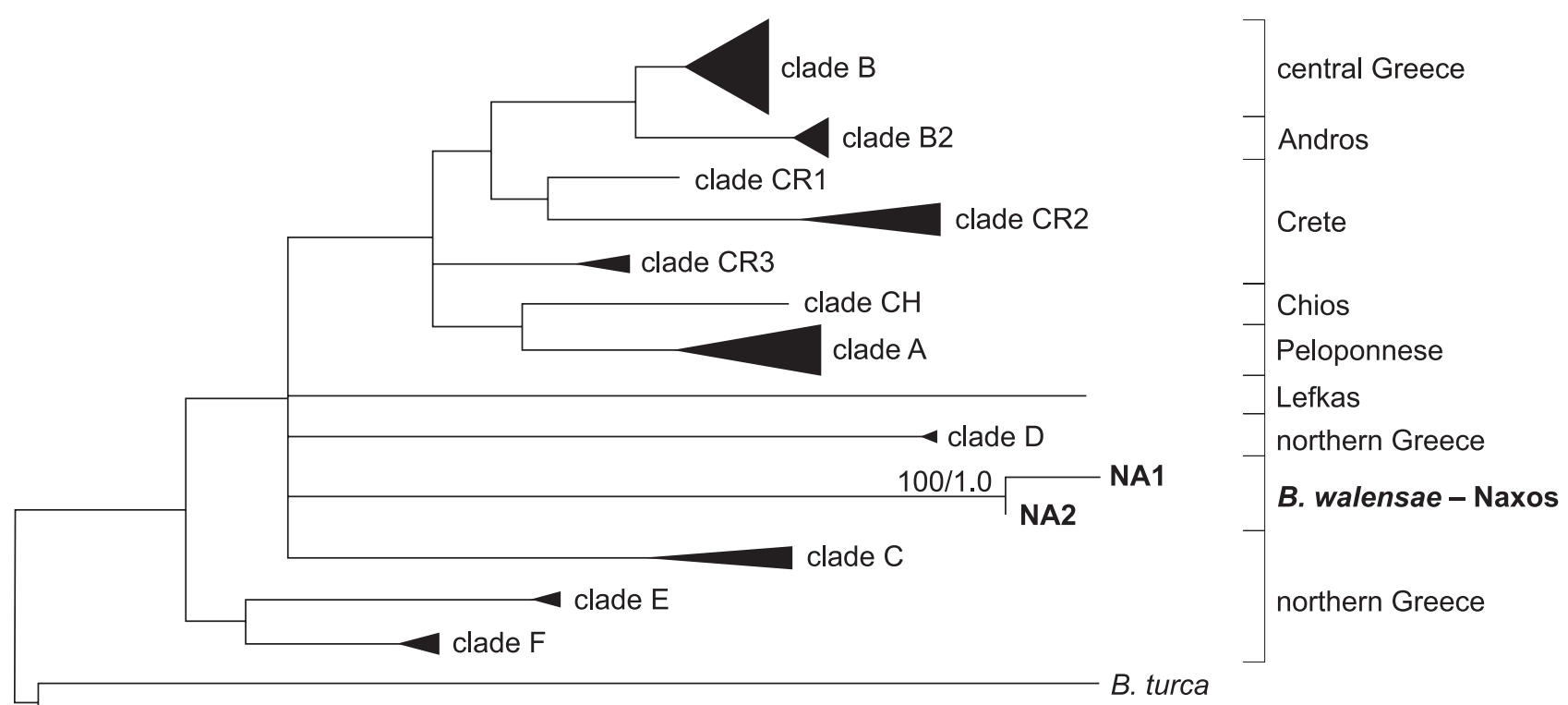

B. austriaca

0.01

Fig. 22. Maximum likelihood tree for COI for the main clades of the Greek Bythinella, modified from SzAROwSKA et al. 2016; triangles indicate groups of several close haplotypes

face had the highest loading in PC2. Thus, as could be seen in Fig. 23, the shells of B. walensae could be distinguished based on their height, spire height and aperture height, thus their slenderness, although the variability range overlapped the ones of some other clades. The same overlap is true of the female reproductive organs and penes. This is, however, a normal picture within the Truncatelloidea (FALNIOWSKI 1987, 1992, FALNIOWSKI et al. 2012a, b). One could either consider one or a few specimens of each species

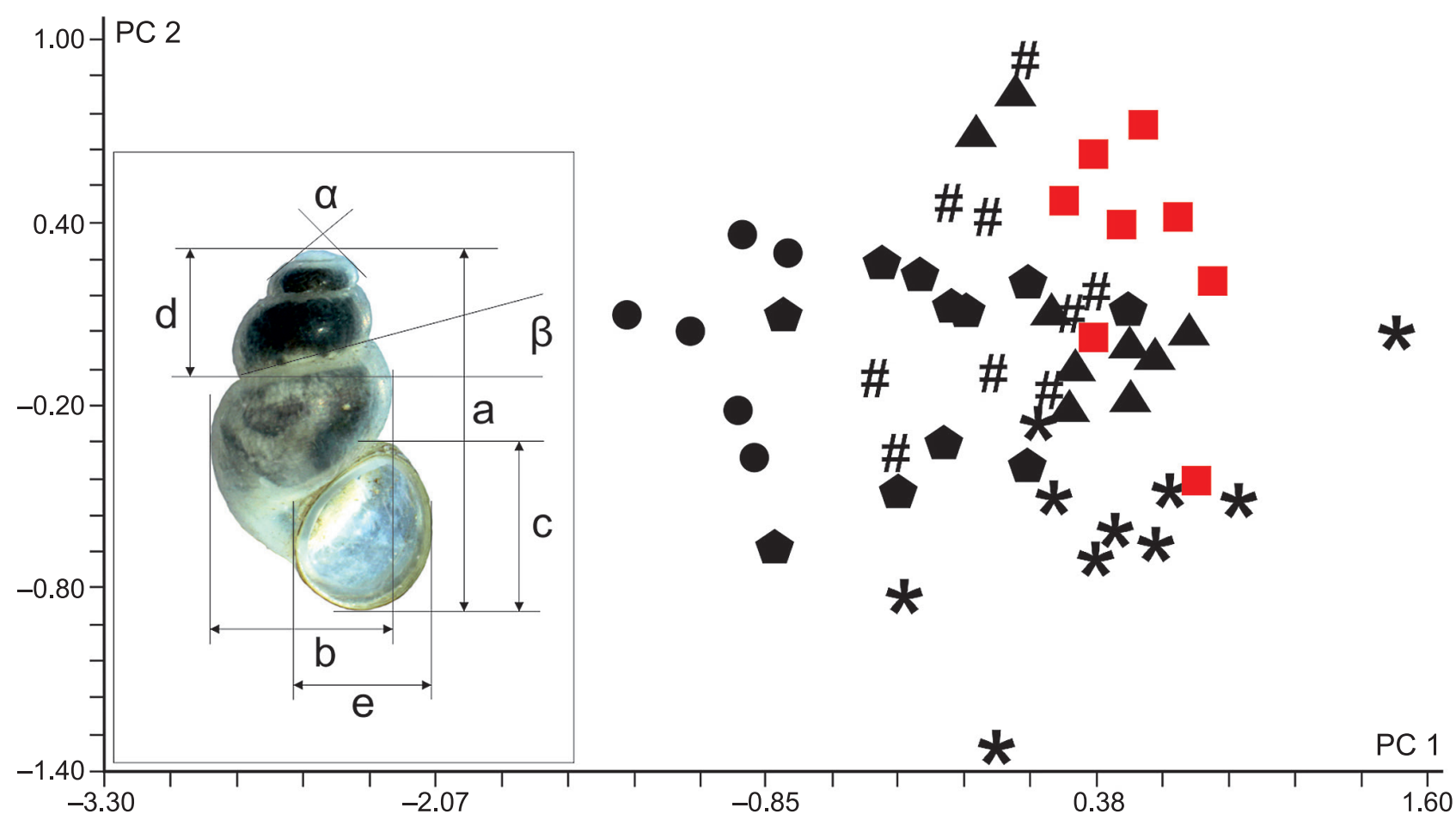

Fig. 23. PCA on the seven shell morphometric parametres, defined on the shell shown at the left side (for characters and mean values see Table 1); red squares represent Bythinella walensae, black symbols - the other clades from the Aegean; based on SZAROWSKA et al. 2016 
and, then, discover evident differences between the species, or study numerous specimens of each nominal taxon - and see the (nearly) continuous variation. Morphological characters within the Truncatelloidea usually lack the states which are unique, or characteristic at least, the ranges of variation are nearly always wide and overlap between the species or even genera (e.g. FALNIOWSKI 1987, SZAROWSKA \& FALNIOWSKI
2008, FALNIOWSKI \& SZAROWSKA 2011, FALNIOWSKI et al. 2012a, SZAROWSKA et al. 2016). On the other hand, species identification with DNA sequences is always certain, although species boundaries remain disputable, especially with one locus and small divergence. In the case of $B$. walensae, however, there are two loci, and the p-distances are high (SZAROWSKA et al. 2016).

\section{REFERENCES}

Benke M., Brändle M., Albrecht C., Wilke T. 2009. Pleistocene phylogeography and phylogenetic concordance in cold-adapted spring snails (Bythinella spp.). Mol. Ecol. 18: 890-903. http://dx.doi.org/10.1111/j.1365294X.2008.04073.x

BiChain J. M., Boisselier-Dubayle M. C., Bouchet P., SAMADI S. 2007a. Species delimitation in the genus Bythinella (Mollusca: Caenogastropoda: Rissooidea): A first attempt combining molecular and morphometrical data. Malacologia 49: 293-311. http://dx.doi. org/10.4002/0076-2997-49.2.293

Bichain J. M., GAubert P., SAMADi S., BOISSEliER-DubaYle M. C. 2007b. A gleam in the dark: Phylogenetic species delimitation in the confusing spring-snail genus Bythinella Moquin-Tandon, 1856 (Gastropoda: Rissooidea: Amnicolidae). Mol. Phyl. Evol. 45: 927941. http://dx.doi.org/10.1016/j.ympev.2007.07.018

Boeters H. D. 1973. Die Gattung Bythinella und Gattung Marstoniopsis in Westeuropa, 1. Westeuropäische Hydrobiidae, 4 (Prosobranchia). Proceedings of Fourth European Malacological Congress. Malacologia 14: $271-285$

BoETERS H. D. 1998. Mollusca: Gastropoda: Superfamilie Rissooidea. In: SCHWOERBEL J., ZWICK P. (eds). Süsswasserfauna von Mitteleuropa. Begründet von A. Brauer, 5/1-2, Gustav Fischer Verlag, Jena - Lübeck Ulm, pp. 1-76.

FALNIOWSKI A. 1987. Hydrobioidea of Poland (Prosobranchia: Gastropoda). Folia Malacol. 1: 1-122.

FALNIOWSKI A. 1992. Genus Bythinella Moquin-Tandon, 1855, in Poland (Gastropoda, Prosobranchia, Hydrobiidae. In: GITTENBERGER E., GOUd J. (eds), Proceedings of the Ninth International Malacological Congress (Edinburgh, 31 August - 6 September 1986), Leiden: 135-138.

FALNIOWSKI A., HORSÁK M., SZAROWSKA M. 2009a Bythinella hansboetersi Gloeer et Pesic, 2006 (Gastropoda:Rissooidea) in Bulgaria: its morphology, molecular distinctness, and phylogeography. Folia Malacol. 17: 23-32. http://dx.doi.org/10.2478/ v10125-009-0002-3

FALNIOWSKI A., SZAROWSKA M. 2011. Radiation and phylogeography in a spring snail Bythinella (Mollusca: Gastropoda: Rissooidea) in continental Greece. Ann. Zool. Fenn. 48: 67-90. http://dx.doi. org/10.5735/086.048.0201
FALNIOWSKI A., SZAROWSKA M. 2012. Sequence-based species delimitation in the Balkan Bythinella MoquinTandon, 1856 (Gastropoda: Rissooidea) with general mixed Yule coalescent model. Folia Malacol. 20: 111120. http://dx.doi.org/10.2478/v10125-012-0017-z

FALNIOWSKI A., SZAROWSKA M., GLÖER P., PEŠIĆ V., GeORGIEV D., HoRsÁK M., SiRBU I. 2012a. Radiation in Bythinella Moquin-Tandon, 1856 (Mollusca: Gastropoda: Rissooidea) in the Balkans. Folia Malacol. 20: 1-10. http://dx.doi.org/10.2478/v10125-012-0006-2

FALNIOWSKI A., SZAROWSKA M., GLÖER P., PEŠIĆ V. 2012b. Molecules vs. morphology in the taxonomy of the Radomaniola/Grossuana group of Balkan Rissooidea (Mollusca: Caenogastropoda). J. Conchol. 41: 19-36.

FALNIOWSKI A., SZAROWSKA M., SIRBU I. 2009b. Bythinella Moquin-Tandon, 1856 (Gastropoda: Rissooidea: Bythinellidae) in Romania: species richness in a glacial refugium. J. Nat. Hist. 43: 2955-2973. http://dx.doi. org/10.1080/00222930903359636

GiUSTI F., PEZZOLI E. 1977. Primo contributo alla revisione del genere Bythinella in Italia. Natura Bresciana, Annali del Museo Civico di Storia Naturale di Brescia 14: 3-66.

HAAse M., Wilke T., MildNER P. 2007. Identifying species of Bythinella (Caenogastropoda: Rissooidea): a plea for an integrative approach. Zootaxa 1563: 1-16.

HeRshler R., PONDER W. F. 1998. A review of morphological characters of hydrobioid snails. Smithsonian Contrib. Zool. 600: 1-55. http://dx.doi.org/10.5479/ si.00810282.600

RADOMANP. 1976. Speciation within the family Bythinellidae on the Balkans and Asia Minor. Z. Zool. Syst. Evol. 14: 130-152. http://dx.doi.org/10.1111/j.1439-0469.1976. tb00522.x

RADOMAN P. 1983. Hydrobioidea a superfamily of Prosobranchia (Gastropoda). I. Systematics. Serbian Academy of Sciences and Arts, Monograph 547, Department of Sciences 57: 1-256.

REISCHÜtZ A., REISCHÜTZ P., FISCHER W. 2008. Hellenica pantoia 22: Zur Verbreitung der Gattung Bythinella Moquin-Tandon 1856 (Gastropoda: Prosobranchia: Hydrobiidae) auf der Peloponnes (Griechenland). Nachrichtenblatt der Ersten Vorarlberger Malakologischen Gesellschaft 15: 35-36.

SCHÜTT H. 1980. Zur Kenntnis griechischer Hydrobiiden. Arch. Molluskenkd. 110: 115-149. 
SZAROWSKA M. 2006. Molecular phylogeny, systematics and morphological character evolution in the Balkan Rissooidea (Caenogastropoda). Folia Malacol. 14: 99168. http://dx.doi.org/10.12657/folmal.014.014

SZAROWSKA M., FALNIOWSKI A. 2008. There is no philosopher's stone: coup de grace for the morphology-based systematics in the rissooidean gastropods? 5 th Congress of the European Malacological Societies, Ponta Delgada: 28.
SZAROWSKA M., OSIKOWSKI A., HOFMAN S., FALNIOWSKI A. 2016. Do diversity patterns of the spring-inhabiting snail Bythinella (Gastropoda, Bythinellidae) on the Aegean Islands reflect geological history? Hydrobiologia 765: 225-243. http://dx.doi.org/10.1007/s10750-0152415-x

Received: March 3rd, 2016

Revised: June 17th, 2016

Accepted: June 23rd, 2016

Published on-line: July 19th, 2016 